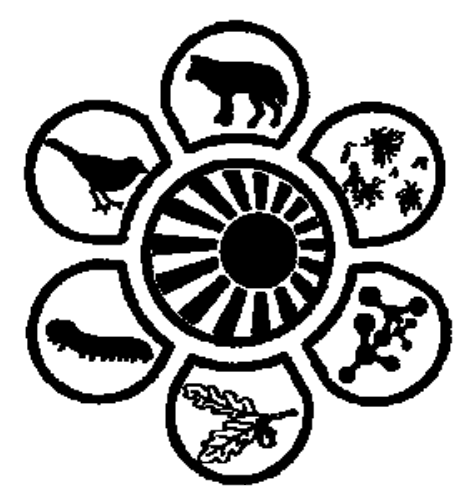

Вісник Дніпропетровського університету. Біологія, екологія.

Vìsnik Dnìpropetrovs'kogo unìversitetu. Seriâ Bìologiâ, ekologiâ

Visnyk of Dnipropetrovsk University. Biology, ecology.

Vìsn. Dnìpropetr. Unìv. Ser. Bìol. Ekol. 2014. 22(2), 133-144.

doi:10.15421/011419

ISSN 2310-0842 print

ISSN 2312-301X online

www.ecology.dp.ua

УДК 581.522.4(292.486) (477)

\title{
Фенотипічна мінливість листків рослин роду $A$ cer, інтродукованих у степову зону України
}

\author{
I.О. Зайцева, М.М. Поворотня
}

Дніпропетровський національний університет імені Олеся Гончара, Дніпропетровськ, Украӥна

\begin{abstract}
Запропоновано алгоритм статистичного аналізу неоднорідності морфоструктурних ознак листя та диференціації їх величин на дискретні групи, який полягає у послідовному виділенні складових компонент нормального виду з інтегральної кривої розподілу ознаки. Досліджено особливості мінливості питомої ваги листка у видів роду Acer L., інтродукованих у різних районах степової зони України. Адаптація кленів до ксеротермних факторів середовища пов'язана зі змінами співвідношення груп варіювання ознаки та їх внеску до сумарної вибірки. Установлено пряму залежність щільності імовірності прояву (фенотипічної реалізації) ознаки у певному діапазоні варіювання та ступеня адаптованості, або відповідності організму певним умовам середовища. Для видів із найвираженішими ксероморфними ознаками (A. campestre, A. tataricum, A. monspessulanum) властиве послідовне збільшення як середньої величини одного з компонентів кривої розподілу ознаки питомої ваги листя, так і його внеску до сумарної вибірки в міру посилення гідротермічного стресу. У малостійких видів кленів імовірність прояву ознаки в різних районах степової зони практично рівнозначна для кожного з виділених компонентів сумарної вибірки, що свідчить про відсутність у цих видів адаптивного потенціалу, який може бути реалізований у даних умовах середовища. Екокліматична адаптація мезофітних видів клена проявляється у звуженні довірчих інтервалів складових компонентів сумарної кривої, зменшенні загального інтервалу варіювання питомої ваги листя та спрямована на зниження фенотипічного поліморфізму в умовах степової зони.
\end{abstract}

Ключові слова: адаптивний потенціал; ксероморфність листків; посушливі умови; питома вага листя; варіабельність ознаки

\section{Phenotypic variability of plant leaves of Acer genus, introduced into steppe zone of Ukraine}

\section{I.O. Zaitseva, M.M. Povorotnaya}

This paper deals with studying of the patterns of ecological adaptation of wood species of Acer L. genus during their introduction into steppe zone of Ukraine. Hydrothermal conditions of the growing season in steppe zone of Ukraine are particularly unfavorable for tree and shrubbery plantings, comprising both native and introduced species. In the course of plants' introduction, adaptive changes occur; such changes represent the spectrum of phenotypic implementation of the definite genotype under the influence of new environmental conditions. Stress environment of the region of introduction leads to occurrence of a great variety of phenotypic forms, as the different variants of genotype implementation. Studying of phenotypic variability gives an opportunity to determine the capacity to adaptation of introduced species and ways of adaptive reactions in new conditions of living. Therefore, objective of the work consists in studying of the processes of differentiation of morphological characters in species of Acer genus introduced in the regions of steppe zone with varying intensity of hydrothermal factors. Studies were carried out in the central and south-eastern steppe regions, as well as in the south of steppe zone in the coastal and continental areas. Subjects of research were 9 species of maples, differing by their botanic and geographic origin and by the degree of drought resistance in the steppe zone of Ukraine. Patterns of variability of morphostructural characters of leaves were determined by the indicator of specific weight of leaves which was calculated as a ratio of weight of dry laminas to their area $\left(\mathrm{mg} / \mathrm{cm}^{2}\right)$. Following the results of study, it was found that adaptation of maples to xerothermic factors of the environment is connected with changing of the ratio of groups of character variation and their contribution into total sample. Direct relationship is established between the probability density of expression (phenotypic implementation) of the character in the definite range of variation and degree of adaptation of the plant. Typical feature of species with the most prominent xeromorphic characters (A. campestre, A. tataricum, A. monspessulanum) is gradual increase in both the mean value of one of the components of the leaves' specific weight distribution curve and its contribution in the total sample with

Дніпропетровський національний університет ім. Олеся Гончара, пр. Гагаріна, 72, Дніпропетровськ, 49010, Украӥна Oles' Honchar Dnipropetrovsk National University, Gagarin Ave., 72, Dnipropetrovsk, 49010, Ukraine

Tel.:+38-097-437-02-76.E-mail: irinza_ldfr@mail.ru 
the increasing hydrothermal stress. In maple species with low stability, probability of the character display is actually the same for each segregate component of total sample in the different regions of steppe zone, which indicates that these species has no adaptive potential to be realized in the specific environment. Eco-climatic adaptation of mesophytic maple species is displayed in reduction of confidence intervals in the segregate components of the integral curve and reduction of total interval of variation of specific weight of leaves, i.e. it is aimed at decrease in phenotypic polymorphism of introduced species of Acer genus in the drought conditions of steppe zone of Ukraine.

Keywords: adaptive potential; leaf xeromorphic characters; drought conditions; specific weight of leaves; character variation

\section{Вступ}

Створення в умовах степової зони штучних насаджень різного призначення - рекреаційних, захисних, лісопаркових - дозволяє ефективно виконувати завдання оптимізації якості навколишнього середовища, озеленення населених міст і рекультивації техногенних територій, сприяє підвищенню рівня біологічного різноманіття на регіональному рівні (Bulakhov et al., 2003; Pakhomov and Brygadyrenko, 2005; Pakhomov et al., 2011; Bobyliov et al., 2014). Зважаючи на те, що склад природної дендрофлори степової зони досить обмежений, а в культурі використовується невелика іiі частка, питання інтродукції декоративних видів і залучення їх до озеленення залишається одним із найактуальніших напрямів біоекологічних досліджень. Поряд із цим інтродукція рослин - широкий екологічний та фітогеографічний експеримент (Burda, 1991), який дозволяє виявити пристосувальні можливості рослинних організмів, їх екологічну амплітуду, структурну та функціональну мінливість.

Під впливом стресових факторів відбувається адаптація рослин до нових умов існування, відновлення або заміщення пошкоджених структур, стабілізація функціонування на новому рівні метаболічних процесів з утворенням певного фенотипу як прояву морфогенетичної адаптивної відповіді (Kapustyan and Zhuk, 2009; Fang et al., 2012; Niinemets and Kull, 2003), до якої належить i регуляція проліферативних процесів у тканинах вегетативних органів і формування морфологічних ознак їх ксероморфності. В умовах водного стресу розвиток ксероморфної будови листків виступає як основний механізм посухостійкості рослин (Rum'yankov, 2009; Chen et al., 2010; Aranda et al., 2004).

Стресові умови району інтродукції викликають виникнення великого різноманіття фенотипічних форм як різних варіантів реалізації генотипу. Процес зростання поліморфності ознак інтродуцентів розглядається як фенотипічне розкриття мобілізаційних резервів мінливості (Kordyum, 2001). Оптимальними для конкретних рослин є умови, які викликають у них мінімальні зміни морфологічних ознак і фізіологічних функцій, а посилення мінливості інтродуцентів відмічається у міру віддалення інтродукційного пункту від меж природного ареалу (Shavrov, 1961). Адаптація організму в онтогенезі, яка досягається за рахунок модифікаційної мінливості ознак, зумовлює формування різних фенотипів, що спостерігається й у генетично близьких індивидів.

Статистичні показники мінливості, які застосовуються для кількісної оцінки норми реакції, ще не визначають міри іï адаптивності. Тобто висока фенотипічна пластичність ознаки може підвищувати або знижувати пристосованість до умов середовища. Для кількісної оцінки динамічної норми недостатньо визначення середніх величин ознаки та їі нормального відхилення, які характеризують стан рослин за умов впливу зовнішніх факторів (Zaytcev, 1983; Brendan et al., 2006). У зв'язку із цим актуальною $є$ розробка кількісних методів оцінки відповідності умов середовища діапазону екологічного оптимуму рослин, як власне і величини цього діапазону для різних видів інтродуцентів. Морфоанатомічні зміни слугують зовнішніми показниками шляхів адаптивних пристосувань рослин до факторів середовища (Zhuangat et al., 2010). Одним із факторів, що найбільшою мірою змінюють морфологію рослин, є гідротермічний режим, а найпластичнішим 3 органів рослин вважається листок (його форма, розміри, а також продиховий і пластидний апарати).

Мета цього дослідження - оцінити процеси морфологічної диференціації ознак листків під впливом посушливих умов у представників роду Acer L., інтродукованих у різних районах степової зони України.

\section{Матеріал і методи досліджень}

Район досліджень належить до континентальної степової області з нестійким зволоженням і різним ступенем вираженості посушливо-суховійних явищ. Дослідження проводили у провідних інтродукційних осередках степової зони України - ботанічних садах і дендропарках, розташованих у районах із різною напруженістю гідротермічних умов протягом вегетаційного періоду: у Центральному Степу - Ботанічний сад Дніпропетровського національного університету та Криворізький ботанічний сад НАНУ, у південно-східній частині Степу 3 найвираженішою континентальністю клімату - Донецький ботанічний сад НАНУ, у південному континентальному Степу - Біосферний заповідник «Асканія-Нова» НААНУ, у південному приморському Степу - Ботанічний сад Одеського національного університету. Райони досліджень належать до різних областей і провінцій за кліматичним, фізико-географічним і геоботанічним районуванням території України. Для проведення порівняльного аналізу до вивчення залучали колекції Національного ботанічного саду НАНУ в Києві, розташованого в зоні мішаних лісів зі сприятливими для деревних порід лісорослинними умовами.

Об'єкти досліджень - дев'ять видів роду Acer, що різняться за посухостійкістю та природним походженням, більшість 3 яких інтродуковано у степову зону 3 різних ботаніко-географічних областей. Більшість європейських та східноазіатських видів кленів у районах природного зростання приурочені до умов помірного та досить вологого клімату, тіньовитривалі, за потребою до вологості грунту належать до мезофітів (Kohno, 1982). Серед них вимогливішими до умов зволоження $\epsilon$ A. pseudoplatanus L. (клен явір), A. ginnala Maxim. (клен прирічковий); менш вимогливі $A$. platanoides L. (клен гостролистий), $A$. campestre L. (клен польовий); досить посухостійкі A. tataricum L. (клен татарський), A. semenovii Rgl. et Herd (клен Семенова). Деякі північноамериканські 
клени за екологічними властивостями $є$ мезогігрофітами (A. saccharinum L. - клен сріблястий), середземноморські ксеромезофітами (A. monspessulanum L. - клен монпелійський), здатними витримувати досить сильну посуху. Високу життєздатність в умовах степової зони показав північноамериканський A. negundo L. (клен ясенелистий).

Закономірності змін морфоструктурних ознак листків визначали за показником питомої ваги поверхні листя, який розраховували за H.G. Tooming (1984) як співвідношення маси сухих листкових пластинок до їх

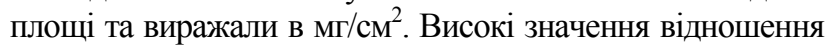
об’єму (сухої маси) до поверхні (площі) листка є однією 3 найхарактерніших ознак ксероморфних листків, пов'язаних із певними внутрішніми показниками, такими як збільшення механічної міцності листків, потовщення оболонок клітин, розвиток склеренхіми та кутикули (Raskatov, 1979; Borysyuk et al., 1989; Waring, 1983; Feng et al.,
2013). Розвиток таких особливостей будови викликає збільшення сухої маси тканини листка та, відповідно, зростання відношення об'єму до поверхні.

Для статистичного аналізу отриманих даних застосовували оригінальний метод розкладання сумарних кривих щільності імовірності варіювання ознаки (Zaitseva, 2012). Показник питомої ваги листя інтродуцентів визначали у вибірці обсягом не менше 60 дат, $з$ якої формували зважений варіаційний ряд із 15 класів та визначали частоту трапляння величини ознаки питомої ваги для кожного класу $(n / N)$. У графічному вираженні за цими даними отримували сумарну криву розподілу величин ознаки, яка у більшості випадків помітно відхилялася від нормального розподілу та мала вигляд багатовершинної та асиметричної кривої (рис. 1), що свідчить про неоднорідність розподілу ознаки та, у зв'язку із цим, про складовий характер кривої.

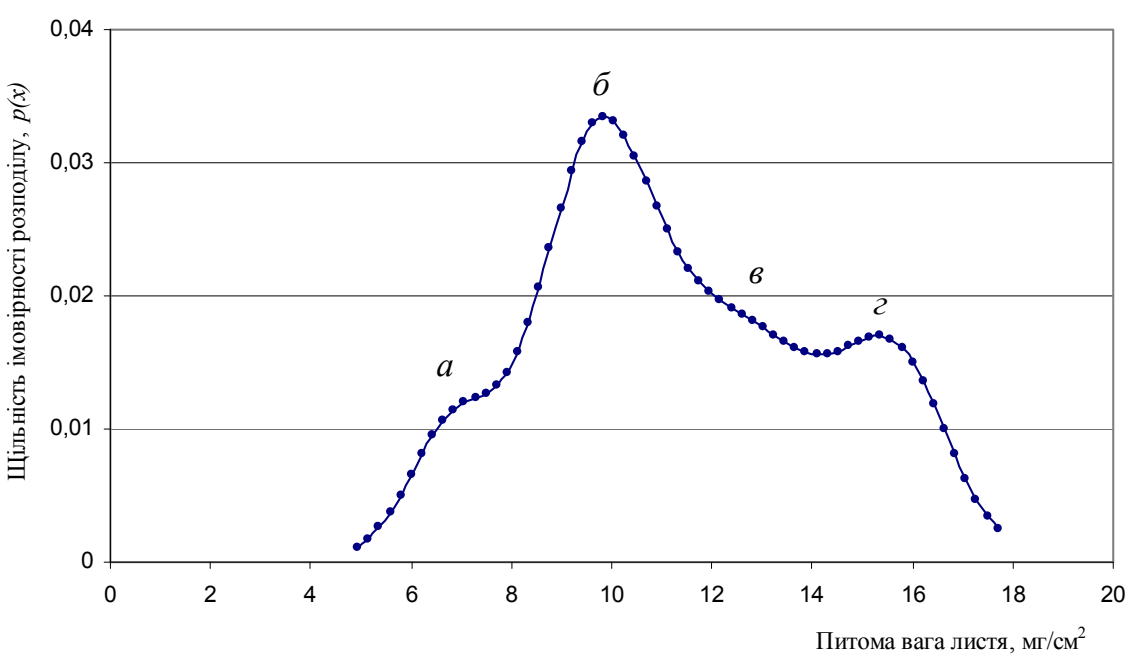

Рис. 1. Приклад сумарної кривої розподілу питомої ваги листків клена: $a-1$-й фрагмент кривої, $\sigma$ - 2-й фрагмент, в - 3-й фрагмент, г-4-й фрагмент

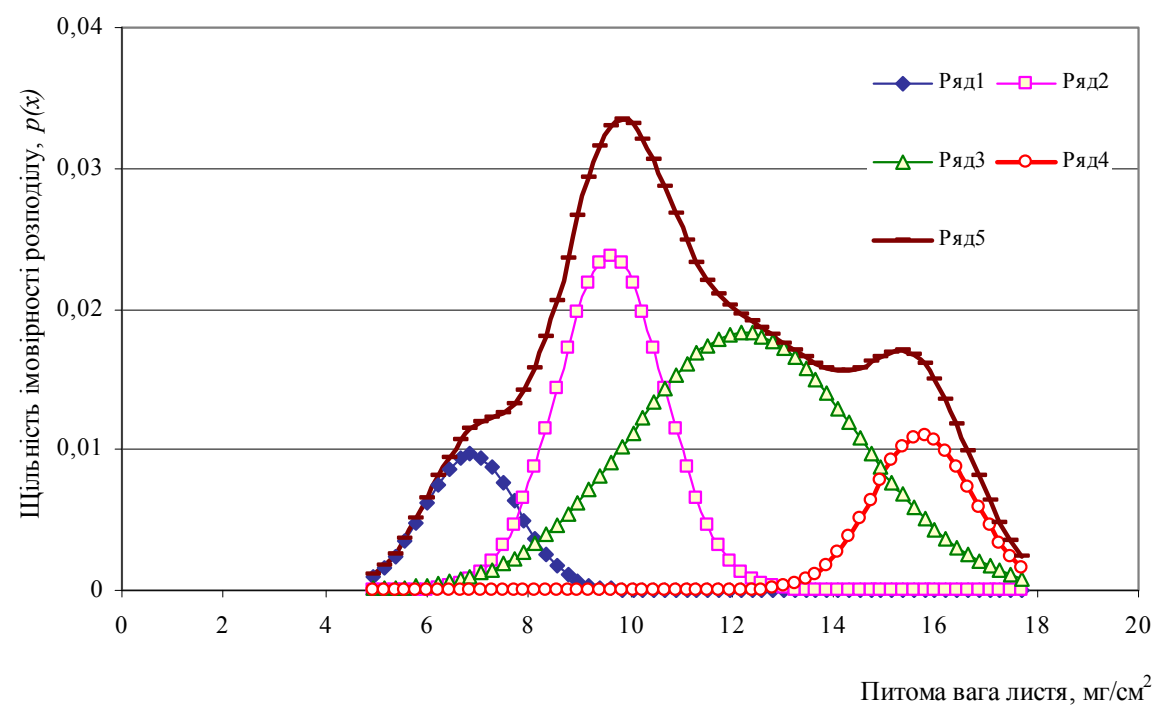

Рис. 2. Інтегральне подання розкладання сумарної кривої розподілу питомої ваги листків на складові компоненти: ряди 1-4 - компоненти сумарної кривої розподілу, ряд 5 - сумарна крива розподілу величин

Ми припустили, що сумарна крива огинає декілька складових іiі компонентів, кожен з яких наближається до кривої нормального розподілу та відповідає окремій групі розподілу ознаки. Для того, щоб виявити складові компоненти сумарної кривої, значення кривої апроксимували Spline-кривою у програмі Excel. Цю комп’ютерну програму 
застосовували 3 метою отримання додаткових проміжних точок в інтегральній кривій розподілу та проведення послідовного розкладання кривої на окремі компоненти, які описуються формалізмом нормального розподілу.

Кількість компонент звичайно дорівнювала кількості піків сумарної кривої, хоча деякі неявні піки ( $a$ і в на рис. 1) проявлялися в контурі сумарної кривої у міру видалення попередніх компонентів. Контроль достовірності виділення складових кривих проводили за нормувальним принципом: сума площ, обмежених складовими кривими, повинна дорівнювати площі, обмеженій інтегральною кривою. Даний критерій у наших розрахунках практично завжди відповідав величинам, близьким до 0,95.

Таким чином, вихідна крива розподілу морфометричних ознак листя являє собою суму складових компонентів (рис. 2), які показують окремі діапазони ознаки з найбільшою імовірністю трапляння по кожному діапазону. Кількість діапазонів дорівнює кількості виділених компонентів кривої і, відповідно, кількості пиків сумарної кривої. В усіх випадках при отриманні нормальних розподілів окремих компонентів сумарної кривої для них розраховували значення параметрів амплітуди $(A)$ розподілу, середньоквадратичного відхилення (SD) та середнє значення $(x)$.

Запропонований алгоритм виділення компонентів із сумарної кривої дозволяє установити кількісні параметри, що характеризують кожний компонент $(A, \sigma, x)$, чого не можна зробити на основі традиційної кривої зваженого варіаційного ряду, а також провести порівняльний аналіз варіювання цих параметрів у рослин у різних умовах зростання. Кількість компонентів сумарної кривої свідчить про ступінь неоднорідності листкового апарату інтродукованих рослин, що дає можливість оцінити характер мінливості морфоструктурних ознак листя та диференціювати їх на окремі репрезентативні групи у різних пунктах інтродукції видів роду Acer.

\section{Результати та їх обговорення}

В умовах степової зони інтродуковані рослини одночасно піддаються впливу підвищеної інсоляції та складних гідротермічних факторів, що безперечно відбивається на морфоструктурних ознаках листя i, відповідно, на величині питомої ваги листя. Цей показник дозволяє порівнювати види за ступенем ксероморфності структури листя, тобто за збільшенням сухої ваги листя, нормованої на одиницю площі листкової поверхні. Дані щодо розподілу питомої ваги листя видів роду Acer у різних районах інтродукції у степовій зоні та у Києві наведені в таблиці, графічно відображені у сумарних кривих розподілу та їх складових компонентів на рисунках 3-8.

Аналіз статистичних параметрів сумарних вибірок (табл.) свідчить про існування достовірних відмінностей між середніми значеннями питомої ваги листя більшості видів кленів, що культивуються у ботанічних осередках двох різних природно-кліматичних зон України степової зони та на межі лісостепової та лісової зон. В останньому випадку у сприятливіших умовах вегетації відмічаються найбільші середні значення питомої ваги листка у таких видів кленів як A. pseudoplatanus i $A$. saccharinum. Накопичення сухої маси листка досить активно відбувається у цих видів у ботанічних осередках Кривого Рогу та Донецька - у тих районах центрального та східного Степу, які відзначаються найменш ксеротермними умовами порівняно $з$ південним Степом.

Таким чином, за показниками середніх значень питомої ваги листка A. pseudoplatanus i A. saccharinum характеризуються як найбільш мезофітні, у яких в умовах гідротермічного стресу у Південному Степу гальмуються процеси акумуляції органічної речовини в листках.

В іншу групу можна виділити $A$. platanoides, $A$. Tataricum, $A$. campestre, $A$. semenovii та $A$. ginnala, у яких статистичні параметри сумарної вибірки питомої ваги листка досягають найбільших значень у районах Центрального та Південно-Східного Степу - у ботанічних садах Дніпропетровська, Кривого Рогу та Донецька (табл.). Перші три види природно зростають у байрачних лісах Центрального Степу, тому у сприятливих для них умовах природного ареалу активно відбуваються процеси фотоасиміляції, накопичення органічної маси листка та, відповідно, зростання питомої ваги листка. Така спрямованість фізіологічних процесів, про яку ми судимо за показниками питомої ваги листка, характерна для A. semenovii та A. ginnala, інтродукованих у ці ботанічні осередки. Зниження показника питомої ваги листя у південних районах степової зони свідчить про порушення процесів обміну пластичних речовин у листках цієї групи кленів.

Параметри розподілу питомої ваги листя видів роду Acer у різних умовах інтродукції у степовій зоні

Табличя

\begin{tabular}{|c|c|c|c|c|c|c|c|c|c|c|}
\hline \multirow{3}{*}{$\begin{array}{c}\text { Об’єкти } \\
\text { досліджень }\end{array}$} & \multirow{3}{*}{$\begin{array}{c}\text { Райони } \\
\text { досліджень }\end{array}$} & \multirow{3}{*}{ 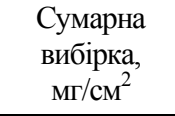 } & \multicolumn{8}{|c|}{ Складові компоненти сумарної кривої розподілу питомої ваги листя } \\
\hline & & & \multicolumn{2}{|c|}{ 1-й компонент } & \multicolumn{2}{|c|}{ 2-й компонент } & \multicolumn{2}{|c|}{ 3-й компонент } & \multicolumn{2}{|c|}{ 4-й компонент } \\
\hline & & & $x \pm \mathrm{SD} \cdot \mathrm{t}_{0,05}$ & $n$ & $x \pm \mathrm{SD} \cdot \mathrm{t}_{0,05}$ & $n$ & $x \pm \mathrm{SD} \cdot \mathrm{t}_{0,05}$ & $n$ & $x \pm \mathrm{SD} \cdot \mathrm{t}_{0,05}$ & $n$ \\
\hline 1 & 2 & 3 & 4 & 5 & 6 & 7 & 8 & 9 & 10 & 11 \\
\hline \multirow{6}{*}{ A. platanoides } & \begin{tabular}{|l|} 
Дніпропет- \\
ровськ
\end{tabular} & $3,17 \pm 0,064^{*}$ & $\begin{array}{c}2,47 \pm \\
0,077\end{array}$ & 0,127 & $\begin{array}{c}3,05 \pm \\
0,091\end{array}$ & 0,421 & $\begin{array}{c}3,48 \pm \\
0,054\end{array}$ & 0,452 & - & - \\
\hline & Кривий Ріг & $6,18 \pm 0,106^{*}$ & $\begin{array}{c}4,56 \pm \\
0,214 \\
\end{array}$ & 0,072 & $\begin{array}{l}6,02 \pm \\
0,132\end{array}$ & 0,588 & $\begin{array}{c}6,80 \pm \\
0,086\end{array}$ & 0,339 & - & - \\
\hline & Донецьк & $3,72 \pm 0,091 *$ & $\begin{array}{c}3,11 \pm \\
0,095\end{array}$ & 0,452 & $\begin{array}{c}4,08 \pm \\
0,119\end{array}$ & 0,379 & $\begin{array}{l}4,51 \pm \\
0,175\end{array}$ & 0,168 & - & - \\
\hline & \begin{tabular}{|l|} 
Асканія- \\
Нова
\end{tabular} & $4,03 \pm 0,084^{*}$ & $\begin{array}{c}3,58 \pm \\
0,085\end{array}$ & 0,424 & $\begin{array}{c}4,04 \pm \\
0,120\end{array}$ & 0,289 & $\begin{array}{c}4,42 \pm \\
0,105\end{array}$ & 0,142 & $\begin{array}{c}4,93 \pm \\
0,073\end{array}$ & 0,144 \\
\hline & Одеса & $4,06 \pm 0,093^{*}$ & $\begin{array}{c}3,67 \pm \\
0,085 \\
\end{array}$ & 0,357 & $\begin{array}{c}4,18 \pm \\
0,097 \\
\end{array}$ & 0,521 & $\begin{array}{c}4,93 \pm \\
0,880 \\
\end{array}$ & 0,122 & - & - \\
\hline & Київ & $5,06 \pm 0,238$ & $\begin{array}{c}1,19 \pm \\
0,541\end{array}$ & 0,062 & $\begin{array}{c}4,79 \pm \\
0,288\end{array}$ & 0,610 & $\begin{array}{c}6,29 \pm \\
0,210\end{array}$ & 0,327 & - & - \\
\hline
\end{tabular}


Продовження таблииі

\begin{tabular}{|c|c|c|c|c|c|c|c|c|c|c|}
\hline 1 & 2 & 3 & 4 & 5 & 6 & 7 & 8 & 9 & 10 & 11 \\
\hline \multirow{6}{*}{ A. pseudoplatanus } & \begin{tabular}{|l} 
Дніпропет- \\
ровськ
\end{tabular} & $5,09 \pm 0,144^{*}$ & $\begin{array}{c}4,55 \pm \\
0,128\end{array}$ & 0,433 & $\begin{array}{c}4,92 \pm \\
0,100\end{array}$ & 0,327 & $\begin{array}{c}6,29 \pm \\
0,303\end{array}$ & 0,239 & - & - \\
\hline & Кривий Ріг & $7,39 \pm 0,504$ & $\begin{array}{l}1,79 \pm \\
0,667\end{array}$ & 0,073 & $\begin{array}{c}7,53 \pm \\
0,749 \\
\end{array}$ & 0,593 & $\begin{array}{c}8,35 \pm \\
0,373\end{array}$ & 0,334 & - & - \\
\hline & Донецьк & $4,95 \pm 0,107^{*}$ & $\begin{array}{c}4,05 \pm \\
0,149\end{array}$ & 0,431 & $\begin{array}{l}5,18 \pm \\
0,132 \\
\end{array}$ & 0,291 & $\begin{array}{c}6,56 \pm \\
0,106 \\
\end{array}$ & 0,258 & - & - \\
\hline & \begin{tabular}{|l|} 
Асканія- \\
Нова
\end{tabular} & $6,32 \pm 0,165^{*}$ & $\begin{array}{l}5,52 \pm \\
0,218\end{array}$ & 0,562 & $\begin{array}{l}7,18 \pm \\
0,125\end{array}$ & 0,316 & $\begin{array}{l}7,78 \pm \\
0,314\end{array}$ & 0,122 & - & - \\
\hline & Одеса & $5,00 \pm 0,153 *$ & $\begin{array}{c}4,59 \pm \\
0,136\end{array}$ & 0,500 & $\begin{array}{c}5,12 \pm \\
0,102\end{array}$ & 0,330 & $\begin{array}{c}6,00 \pm \\
0,250\end{array}$ & 0,170 & - & - \\
\hline & Київ & $7,35 \pm 0,178$ & $\begin{array}{c}5,95 \pm \\
0,211\end{array}$ & 0,307 & $\begin{array}{l}7,80 \pm \\
0,188\end{array}$ & 0,593 & $\begin{array}{l}8,92 \pm \\
0,375\end{array}$ & 0,100 & - & - \\
\hline \multirow{6}{*}{ A. campestre } & \begin{tabular}{|l|} 
Дніпропет- \\
ровськ
\end{tabular} & $4,51 \pm 0,075^{*}$ & $\begin{array}{c}4,12 \pm \\
0,123\end{array}$ & 0,145 & $\begin{array}{c}4,54 \pm \\
0,087\end{array}$ & 0,760 & $\begin{array}{c}4,90 \pm \\
0,106\end{array}$ & 0,094 & - & - \\
\hline & Кривий Ріг & $7,54 \pm 0,126$ & $\begin{array}{c}6,89 \pm \\
0,164\end{array}$ & 0,642 & $\begin{array}{c}8,72 \pm \\
0,126\end{array}$ & 0,358 & - & - & - & - \\
\hline & Донецьк & $3,52 \pm 0,104^{*}$ & $\begin{array}{c}4,40 \pm \\
0,093\end{array}$ & 0,104 & $\begin{array}{c}4,90 \pm \\
0,125\end{array}$ & 0,280 & $\begin{array}{l}5,04 \pm \\
0,164 \\
\end{array}$ & 0,336 & - & - \\
\hline & \begin{tabular}{|l|} 
Асканія- \\
Нова
\end{tabular} & $6,59 \pm 0,143$ & $\begin{array}{c}5,63 \pm \\
0,229 \\
\end{array}$ & 0,184 & $\begin{array}{c}6,69 \pm \\
0,115\end{array}$ & 0,688 & $\begin{array}{l}7,40 \pm \\
0,346\end{array}$ & 0,128 & - & - \\
\hline & Одеса & $6,12 \pm 0,179$ & $\begin{array}{c}5,26 \pm \\
0,143\end{array}$ & 0,452 & $\begin{array}{l}6,76 \pm \\
0,172 \\
\end{array}$ & 0,465 & $\begin{array}{l}7,30 \pm \\
0,330 \\
\end{array}$ & 0,083 & - & - \\
\hline & Київ & $6,69 \pm 0,162$ & $\begin{array}{c}5,46 \pm \\
0,264\end{array}$ & 0,239 & $\begin{array}{c}6,45 \pm \\
0,136\end{array}$ & 0,412 & $\begin{array}{l}7,66 \pm \\
0,236\end{array}$ & 0,349 & - & - \\
\hline \multirow{6}{*}{ A. tataricum } & \begin{tabular}{|l} 
Дніпропет- \\
ровськ
\end{tabular} & $7,78 \pm 0,104^{*}$ & $\begin{array}{c}6,89 \pm \\
0,111\end{array}$ & 0,285 & $\begin{array}{c}7,93 \pm \\
0,134\end{array}$ & 0,375 & $\begin{array}{c}8,35 \pm \\
0,155\end{array}$ & 0,339 & - & - \\
\hline & Кривий Ріг & $3,96 \pm 0,097^{*}$ & $\begin{array}{c}3,32 \pm \\
0,076\end{array}$ & 0,261 & $\begin{array}{c}3,65 \pm \\
0,125\end{array}$ & 0,230 & $\begin{array}{l}4,43 \pm \\
0,123\end{array}$ & 0,508 & - & - \\
\hline & Донецьк & $4,34 \pm 0,056^{*}$ & $\begin{array}{c}3,92 \pm \\
0,066\end{array}$ & 0,312 & $\begin{array}{c}4,34 \pm \\
0,078 \\
\end{array}$ & 0,405 & $\begin{array}{l}4,80 \pm \\
0,039 \\
\end{array}$ & 0,283 & - & - \\
\hline & \begin{tabular}{|l} 
Асканія- \\
Нова
\end{tabular} & $5,72 \pm 0,134 *$ & $\begin{array}{l}5,56 \pm \\
0,154\end{array}$ & 0,903 & $\begin{array}{l}7,20 \pm \\
0,317\end{array}$ & 0,097 & - & - & - & - \\
\hline & Одеса & $7,12 \pm 0,341^{*}$ & $\begin{array}{c}6,20 \pm \\
0,413\end{array}$ & 0,440 & $\begin{array}{c}7,53 \pm \\
0,309\end{array}$ & 0,272 & $\begin{array}{c}8,14 \pm \\
0,232 \\
\end{array}$ & 0,288 & - & - \\
\hline & Київ & $6,41 \pm 0,211$ & $\begin{array}{l}5,41 \pm \\
0,447\end{array}$ & 0,168 & $\begin{array}{c}6,58 \pm \\
0,323\end{array}$ & 0,611 & $\begin{array}{l}7,89 \pm \\
0,288\end{array}$ & 0,221 & - & - \\
\hline \multirow{6}{*}{ A. saccharinum } & \begin{tabular}{|l} 
Дніпропет- \\
ровськ
\end{tabular} & $6,21 \pm 0,022^{*}$ & $\begin{array}{c}6,08 \pm \\
0,011\end{array}$ & 0,492 & $\begin{array}{c}6,24 \pm \\
0,027\end{array}$ & 0,242 & $\begin{array}{l}6,39 \pm \\
0,036\end{array}$ & 0,196 & $\begin{array}{l}6,57 \pm \\
0,045\end{array}$ & 0,070 \\
\hline & Кривий Ріг & $6,48 \pm 0,171^{*}$ & $\begin{array}{l}5,48 \pm \\
0,143\end{array}$ & 0,278 & $\begin{array}{l}5,93 \pm \\
0,237\end{array}$ & 0,306 & $\begin{array}{l}6,97 \pm \\
0,286\end{array}$ & 0,159 & $\begin{array}{l}7,92 \pm \\
0,196\end{array}$ & 0,256 \\
\hline & Донецьк & $7,01 \pm 0,079^{*}$ & $\begin{array}{c}6,50 \pm \\
0,088\end{array}$ & 0,229 & $\begin{array}{c}7,03 \pm \\
0,102\end{array}$ & 0,585 & $\begin{array}{c}7,61 \pm \\
0,079 \\
\end{array}$ & 0,185 & - & - \\
\hline & \begin{tabular}{|l|} 
Асканія- \\
Нова
\end{tabular} & $5,21 \pm 0,047^{*}$ & $\begin{array}{c}4,69 \pm \\
0,057\end{array}$ & 0,227 & $\begin{array}{c}4,97 \pm \\
0,063\end{array}$ & 0,266 & $\begin{array}{l}5,44 \pm \\
0,044\end{array}$ & 0,275 & $\begin{array}{c}5,71 \pm \\
0,051\end{array}$ & 0,232 \\
\hline & Одеса & $5,12 \pm 0,063^{*}$ & $\begin{array}{c}4,82 \pm \\
0,974\end{array}$ & 0,309 & $\begin{array}{c}5,08 \pm \\
0,051\end{array}$ & 0,257 & $\begin{array}{l}5,36 \pm \\
0,059\end{array}$ & 0,434 & - & - \\
\hline & Київ & $7,79 \pm 0,126$ & $\begin{array}{c}6,17 \pm \\
0,136\end{array}$ & 0,269 & $\begin{array}{c}6,88 \pm \\
0,223\end{array}$ & 0,144 & $\begin{array}{c}8,76 \pm \\
0,140\end{array}$ & 0,586 & - & - \\
\hline \multirow{6}{*}{ A. negundo } & \begin{tabular}{|l} 
Дніпропет- \\
ровськ
\end{tabular} & $4,11 \pm 0,102^{*}$ & $\begin{array}{c}3,81 \pm \\
0,114\end{array}$ & 0,687 & $\begin{array}{c}4,59 \pm \\
0,138\end{array}$ & 0,237 & $\begin{array}{c}5,27 \pm \\
0,207\end{array}$ & 0,076 & - & - \\
\hline & Кривий Ріг & $4,30 \pm 0,293^{*}$ & $\begin{array}{c}3,26 \pm \\
0,297 \\
\end{array}$ & 0,239 & $\begin{array}{c}4,26 \pm \\
0,266 \\
\end{array}$ & 0,628 & $\begin{array}{c}6,38 \pm \\
0,724 \\
\end{array}$ & 0,132 & - & - \\
\hline & Донецьк & $4,73 \pm 0,148^{*}$ & $\begin{array}{c}4,02 \pm \\
0,205 \\
\end{array}$ & 0,364 & $\begin{array}{c}4,99 \pm \\
0,169 \\
\end{array}$ & 0,488 & $\begin{array}{l}5,63 \pm \\
0,196 \\
\end{array}$ & 0,148 & - & - \\
\hline & $\begin{array}{l}\text { Асканія- } \\
\text { Нова }\end{array}$ & $6,49 \pm 0,186^{*}$ & $\begin{array}{l}5,47 \pm \\
0,225\end{array}$ & 0,224 & $\begin{array}{l}6,30 \pm \\
0,229\end{array}$ & 0,293 & $\begin{array}{l}6,92 \pm \\
0,223\end{array}$ & 0,356 & $7,51 \pm 0,26$ & 0,123 \\
\hline & Одеса & $6,66 \pm 0,221^{*}$ & $\begin{array}{c}5,46 \pm \\
0,270\end{array}$ & 0,145 & $\begin{array}{c}6,70 \pm \\
0,193\end{array}$ & 0,374 & $\begin{array}{c}6,99 \pm \\
0,225\end{array}$ & 0,481 & - & - \\
\hline & Київ & $5,49 \pm 0,235$ & $\begin{array}{c}4,90 \pm \\
0,164\end{array}$ & 0,794 & $\begin{array}{l}, 32 \pm \\
0,616\end{array}$ & 0,119 & $\begin{array}{c}8,45 \pm \\
0,437\end{array}$ & 0,086 & - & - \\
\hline \multirow{5}{*}{ A. semenovii } & \begin{tabular}{|l|} 
Дніпропет- \\
ровськ
\end{tabular} & $6,26 \pm 0,285$ & $\begin{array}{c}4,93 \pm \\
0,257\end{array}$ & 0,188 & $\begin{array}{c}5,91 \pm \\
0,400\end{array}$ & 0,584 & $\begin{array}{c}8,23 \pm \\
0,274\end{array}$ & 0,228 & - & - \\
\hline & Кривий Ріг & $6,25 \pm 0,084$ & $\begin{array}{c}5,77 \pm \\
0,105\end{array}$ & 0,604 & $\begin{array}{c}6,78 \pm \\
0,128\end{array}$ & 0,225 & $\begin{array}{c}7,25 \pm \\
0,113\end{array}$ & 0,171 & - & - \\
\hline & Донецьк & $6,54 \pm 0,208$ & $\begin{array}{c}5,23 \pm \\
0,211\end{array}$ & 0,127 & $\begin{array}{c}6,13 \pm \\
0,163\end{array}$ & 0,305 & $\begin{array}{c}7,05 \pm \\
0,290\end{array}$ & 0,568 & - & - \\
\hline & \begin{tabular}{|l|} 
Асканія- \\
Нова
\end{tabular} & $6,40 \pm 0,247$ & $\begin{array}{c}5,42 \pm \\
0,240\end{array}$ & 0,324 & $\begin{array}{c}6,41 \pm \\
0,299\end{array}$ & 0,653 & $\begin{array}{c}9,14 \pm \\
0,510\end{array}$ & 0,111 & - & - \\
\hline & Одеса & $6,15 \pm 0,306$ & $\begin{array}{c}5,55 \pm \\
0,237\end{array}$ & 0,581 & $\begin{array}{c}6,57 \pm \\
0,377\end{array}$ & 0,311 & $\begin{array}{c}8,21 \pm \\
0,395\end{array}$ & 0,108 & - & - \\
\hline
\end{tabular}


Закінчення таблииі

\begin{tabular}{|c|c|c|c|c|c|c|c|c|c|c|}
\hline \\
\hline 1 & 2 & 3 & 4 & 5 & 6 & 7 & 8 & 9 & 10 & 11 \\
\hline \multirow{5}{*}{ A. ginnala } & $\begin{array}{l}\text { Дніпропет- } \\
\text { ровськ }\end{array}$ & $3,55 \pm 0,066^{*}$ & $\begin{array}{c}2,78 \pm \\
0,119 \\
\end{array}$ & 0,085 & $\begin{array}{l}3,43 \pm \\
0,075\end{array}$ & 0,638 & $\begin{array}{c}4,09 \pm \\
0,067 \\
\end{array}$ & 0,277 & - & - \\
\hline & Кривий Ріг & $6,39 \pm 0,205^{*}$ & $\begin{array}{c}4,90 \pm \\
0,307 \\
\end{array}$ & 0,196 & $\begin{array}{c}6,54 \pm \\
0,227 \\
\end{array}$ & 0,648 & $\begin{array}{l}7,65 \pm \\
0,283 \\
\end{array}$ & 0,155 & - & - \\
\hline & Донецьк & $7,60 \pm 0,294^{*}$ & $\begin{array}{c}5,81 \pm \\
0,296\end{array}$ & 0,245 & $\begin{array}{c}8,01 \pm \\
0,443\end{array}$ & 0,538 & $\begin{array}{c}8,60 \pm \\
0,212\end{array}$ & 0,217 & - & - \\
\hline & \begin{tabular}{|l|} 
Асканія- \\
Нова \\
\end{tabular} & $5,59 \pm 0,244^{*}$ & $\begin{array}{c}4,94 \pm \\
0,280 \\
\end{array}$ & 0,393 & $\begin{array}{c}5,79 \pm \\
0,315 \\
\end{array}$ & 0,532 & $\begin{array}{c}7,63 \pm \\
0,391 \\
\end{array}$ & 0,074 & - & - \\
\hline & Київ & $2,05 \pm 0,238$ & $\begin{array}{c}6,86 \pm \\
0,387 \\
\end{array}$ & 0,299 & $\begin{array}{c}8,29 \pm \\
0,014 \\
\end{array}$ & 0,700 & - & - & - & - \\
\hline \multirow{6}{*}{$\begin{array}{l}\text { A. monspes- } \\
\text { sulanum }\end{array}$} & \begin{tabular}{|l} 
Дніпропет- \\
ровськ
\end{tabular} & $4,25 \pm 0,058^{*}$ & $\begin{array}{c}4,07 \pm \\
0,053 \\
\end{array}$ & 0,678 & $\begin{array}{c}4,45 \pm \\
0,074\end{array}$ & 0,257 & $\begin{array}{c}5,36 \pm \\
0,144 \\
\end{array}$ & 0,064 & - & - \\
\hline & Кривий Ріг & $5,98 \pm 0,896^{*}$ & $\begin{array}{c}5,02 \pm \\
0,592\end{array}$ & 0,379 & $\begin{array}{c}6,57 \pm \\
0,662\end{array}$ & 0,621 & - & - & - & - \\
\hline & Донецьк & $6,73 \pm 0,236^{*}$ & $\begin{array}{l}5,60 \pm \\
0,257 \\
\end{array}$ & 0,235 & $\begin{array}{c}6,90 \pm \\
0,321 \\
\end{array}$ & 0,596 & $\begin{array}{l}7,71 \pm \\
0,223 \\
\end{array}$ & 0,168 & - & - \\
\hline & \begin{tabular}{|l|} 
Асканія- \\
Нова
\end{tabular} & $10,44 \pm 0,256^{*}$ & $\begin{array}{c}7,27 \pm \\
0,354\end{array}$ & 0,143 & $\begin{array}{c}8,28 \pm \\
0,551\end{array}$ & 0,072 & $\begin{array}{c}11,22 \pm \\
0,260\end{array}$ & 0,784 & - & - \\
\hline & Одеса & $9,32 \pm 0,299^{*}$ & $\begin{array}{c}7,25 \pm \\
0,316\end{array}$ & 0,179 & $\begin{array}{c}8,34 \pm \\
0,293\end{array}$ & 0,195 & $\begin{array}{c}10,22 \pm \\
0,296\end{array}$ & 0,626 & - & - \\
\hline & Київ & $8,58 \pm 0,303$ & $\begin{array}{c}6,54 \pm \\
0,412\end{array}$ & 0,154 & $\begin{array}{c}8,33 \pm \\
0,223\end{array}$ & 0,476 & $\begin{array}{c}9,74 \pm \\
0,518\end{array}$ & 0,369 & - & - \\
\hline
\end{tabular}

Примітки: для A. semenovii порівняння сумарних вибірок здійснювали з вибіркою у Дніпропетровську, для інших видів - із вибіркою в Києві; $n$ - частка компонента в сумарному розподілі, нормована до 1,$0 ; *$ - $p<0,05$.

Найвиразніший адаптивний характер змін питомої ваги листя у посушливих умовах Південного Степу відмічено для A. negundo та A. monspessulanum. У ботанічних осередках, розташованих у районах приморського (Одеса) та континентального (Асканія-Нова) Південного Степу у цих видів відмічаються найвищі середні значення питомої ваги листка, що свідчить не тільки про високу активність обміну пластичних речовин, а і про розвиток морфоанатомічних ознак ксероморфності листка. У зв'язку 3 цим необхідне подальше вивчення фізіологобіохімічних i морфолого-анатомічних особливостей адаптації кленів у посушливих умовах степової зони.

Зіставлення середніх величин сумарних вибірок показників площі та питомої ваги листя у різних районах інтродукцї, а також аналіз спрямованості змін морфометричних показників у міру посилення напруженості гідротермічних умов, дозволив виділити види, у яких ці зміни мають найвираженіші риси ксероморфності та полягають у зменшенні площі листя за одночасного зростання його питомої ваги (A. campestre, A. tataricum, A. monspessulanum, A. negundo). Ці види за своїми екологічними якостями, зумовленими природним походженням, належать до стійких у степовій зоні.

A. semenovii, інтродукований із Середньої Азії, також показав високу стійкість, однак у наших дослідженнях у цього виду спостерігається тільки скорочення площі листка при просуванні на південь, тоді як питома вага залишається незмінною. Напевно, анатомічна структура листка $A$. semenovii, сформована у жорстких умовах природного ареалу, виявилася адаптованою і до умов інтродукції у степовій зоні України, тому вона не піддалася помітним змінам. Стосовно $A$. negundo можна зазначити, що, за результатами наших досліджень водообмінних процесів (Zaitseva, 2004), цей вид належить до типових мезофітів, тому морфоструктурні зміни, які мають ксероморфну спрямованість, є одним із механізмів адаптації $A$. negundo до посушливих умов.
У решти видів адаптивні зміни морфоструктурних показників виражені незначно або проявляються по одному з показників. У A. platanoides i A. pseudoplatanus при зменшенні площі листка питома вага майже не змінюється, досягаючи максимуму у Кривому Розі та Києві. Напевно, у південніших районах умови несприятливі для повноцінної фотоасиміляції та накопичення органічної речовини в листках A. platanoides i $A$. pseudoplatanus. 3 іншого боку, часто не спостерігається прояву всіх ознак ксероморфності у рослин за посушливих умов. Ще В.Р. Заленський, який на початку минулого століття вперше глибоко вивчив ці ознаки та виявив закономірності їх формування, дійшов висновку, що у результаті розвитку одного різко вираженого пристосувального показника можуть бути послаблені або зовсім не виражені інші ознаки. Значних змін досліджуваних показників не відмічено і для A. ginnala, хоча вони мають адаптивний характер в умовах Донецька й АсканіїНови. Позитивне значення стосовно адаптації цього виду має також стійке переважання імовірності трапляння одного 3 компонентів сумарної вибірки (від 0,532 до $0,648$ у відносних одиницях, нормованих до 1,0$)$ у різних районах степової зони.

В A. saccharinum зміни площі листка також мало виражені, а питома вага листка у Південному Степу навіть знижується, що свідчить про порушення фотоасиміляції та інших обмінних процесів. Низька стійкість у степовій зоні $A$. saccharinum відбивається на характері диференціації листя за величиною питомої ваги: у більшості випадків (крім Донецька) щільність імовірності практично рівнозначна для кожного 3 виділених компонентів сумарної вибірки $(0,159-0,306)$, що говорить про відсутність у цього виду адаптивного потенціалу, який може бути реалізований у даних умовах середовища. Подібний характер диференціації листя за питомою вагою відмічено в $A$. platanoides i A. pseudoplatanus, що підтверджує недостатній ступінь адаптованості морфоструктурних ознак у цих видів. 
Для видів із найвиразнішими ксероморфними ознаками (A. campestre, A. tataricum, A. monspessulanum) характерне послідовне збільшення як середньої величини одного $з$ компонентів питомої ваги листя, так і його внеску до сумарної вибірки у міру посилення гідротермічного стресу в різних районах інтродукції у степовій зоні (табл.). Чим більша величина щільності імовірності прояву (фенотипічної реалізаціі) ознаки у певному діапазоні варіювання, тим вищий ступінь адаптованості, або відповідності організму даним умовам середовища.

Цей висновок, отриманий за результатами статистичного аналізу масиву експериментальних даних питомої ваги листків кленів, підтверджується також показниками статистичного розподілу площі листків видів роду Acer. Для $A$. campestre максимальна величина одного 3 компонентів кривої розподілу площі листків та його питома вага складали у Дніпропетровську 4,54 $\pm 0,08 \mathrm{~cm}^{2}$ $(0,760)$, у Кривому Розі - 6,89 $\pm 0,16$ cм$^{2}(0,642)$, в АсканіїНові $-6,69 \pm 0,11 \mathrm{~cm}^{2}(0,688)$. В A. tataricum і A. monspessulanum у найжорсткіших умовах Південного Степу значно зростає внесок до сумарної вибірки одного $з$ компонентів.
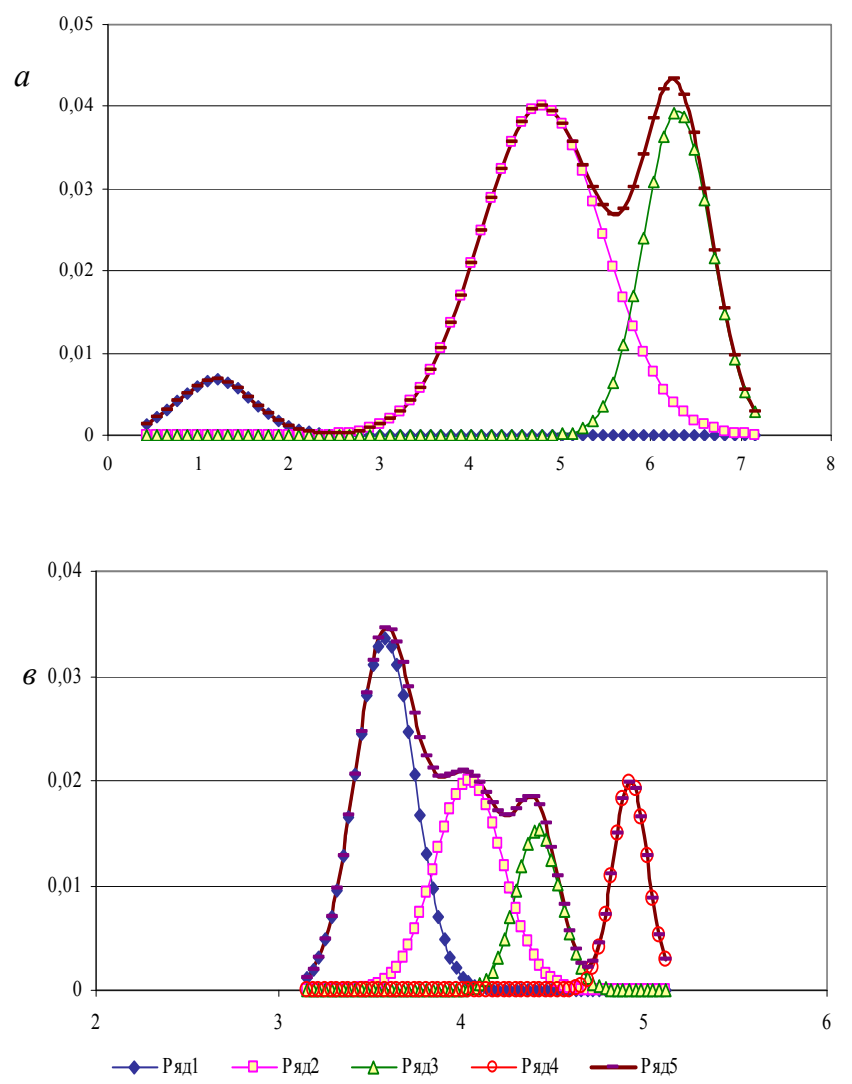

У таких видів як A. semenovi та A. monspessulamum, що показали високу стійкість у степовій зоні, звуження діапазону варіювання ознаки в одному з районів досліджень $€$ лише додатковим механізмом стійкості після адаптивних морфоструктурних перебудов. Для A. tataricum, напевно, це один $з$ основних механізмів стійкості поряд з іншими морфоструктурними змінами, оскільки звуження діапазону варіювання спостерігається в усіх районах степової зони, а в Асканії-Нові залишається тільки два компоненти 3 трьох, причому один із них абсолютно переважає.

Для місцевого посухостійкого A. tataricum, напевно, це один з основних механізмів стійкості поряд з іншими морфоструктурними змінами, оскільки звуження діапа-
У A. tataricum відносна частка, нормована до 1,0, для компоненту 5,56 $\pm 0,15 \mathrm{~cm}^{2}$ складає 0,903; в A. monspessulanum для компонента 3 максимальною величиною 11,22 $\pm 0,26$ $\mathrm{cm}^{2}-0,784$. Для A. negundo, в якого виявлено адаптивний характер змін обох показників, найбільший ступінь диференціації одного 3 компонентів сумарної вибірки спостерігається в Києві $(0,794)$, причому це компонент із найменшою середньою величиною $\left(4,90 \pm 0,16 \mathrm{~cm}^{2}\right)$, що говорить про нестійкий характер пристосувальних морфоструктурних реакцій, пов'язаних із мезофільною спрямованістю фізіологічних процесів водообміну.

Як загальна відповідна реакція на ксеротермні умови районів інтродукції для всіх досліджуваних видів роду Acer, можна відмітити звуження довірчих інтервалів складових компонентів сумарної кривої, а також зменшення загального інтервалу варіювання питомої ваги листя. Ця особливість відмічена у степовій зоні для таких видів як $A$. platanoides, A. pseudoplatanus, A. campestre, A. ginnala, A. negundo (рис. 3-8), що є проявом адаптивних реакцій, спрямованих на зниження фенотипічного поліморфізму у жорстких умовах середовища.

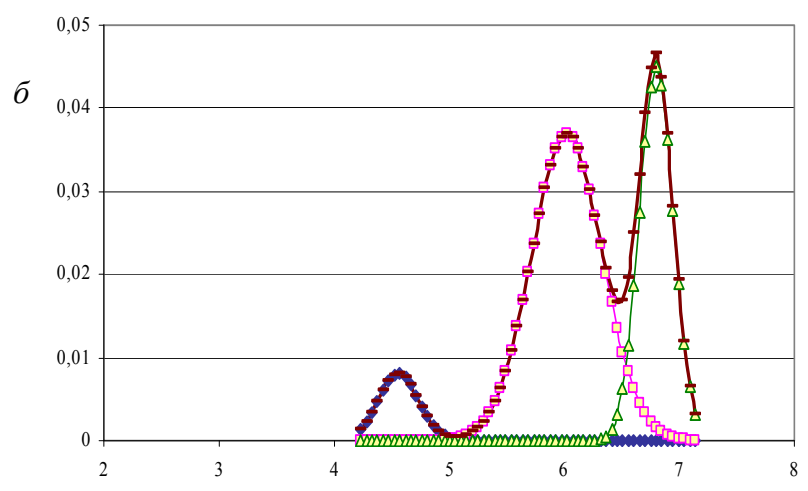

Рис. 3. Групи варіювання та сумарна крива розподілу питомої ваги листя $\boldsymbol{A}$. platanoides: $a$ - Київ, $\sigma$ - Кривий Ріг,, - Асканія-Нова; ряди 1-4 - складові сумарної кривої розподілу, ряд 5 - сумарна крива розподілу питомої ваги листя; за віссю абсцис - питома вага листя, мг $/ \mathrm{cm}^{2}$, за віссю ординат - щільність імовірності розподілу

зону варіювання спостерігається в усіх районах степової зони, а в найстресовіших умовах Південного Степу залишається тільки два компоненти з трьох, причому один iз них абсолютно переважає (рис. 4).

Аналогічний характер мінливості питомої ваги листя спостерігається у досить посухостійких інтродуцентів A. monspessulanum із посушливих районів Середземномор'я (рис. 5) та A. semenovii із Середньої Азії (табл.). В останнього виду питома вага залишається майже незмінною при просуванні інтродукованих рослин у південні райони степової зони. Напевно, анатомічна структура листка $A$. semenovii, сформована у жорстких умовах природного ареалу, виявилася адаптованою і 
тому не піддається помітним змінам в умовах інтродукції у степовій зоні України.

Значних змін досліджуваних показників не відмічено і для A. ginnala, хоча вони мають адаптивний характер в умовах Донецька та Асканії-Нови (табл.). Позитивне значення стосовно адаптації цього виду має також стійке переважання імовірності трапляння одного 3 компонентів сумарної вибірки (від 0,532 до 0,648 у відносних одиницях, нормованих до 1,0) у різних районах степової зони. В $A$. saccharinum питома вага листка у Південному
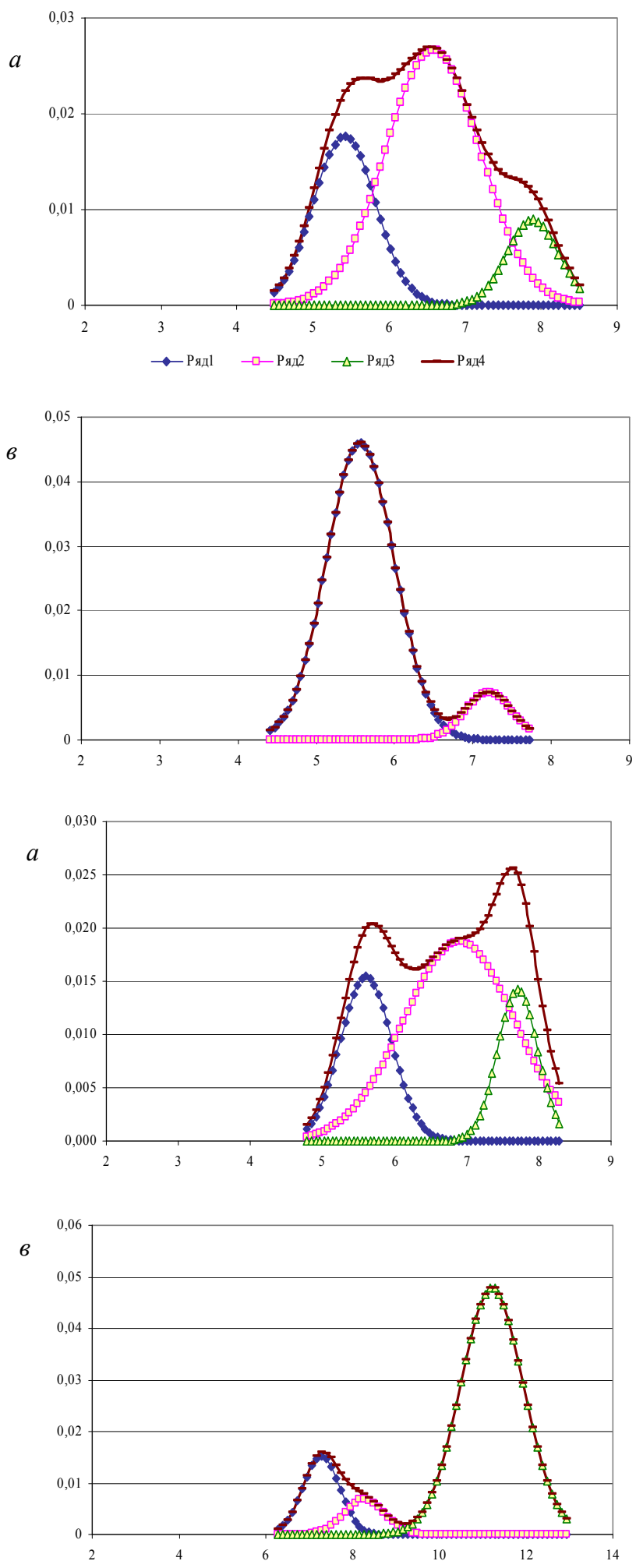

Степу навіть знижується, що свідчить про порушення фотоасиміляції та інших обмінних процесів. Низька стійкість у степовій зоні $A$. saccharinum відбивається на характері диференціації листя за величиною питомої ваги (рис. 6): у більшості випадків, крім Донецька, щільність імовірності прояву ознаки практично однакова для кожного 3 виділених компонентів сумарної вибірки (0,159-0,306), що свідчить про відсутність у цього виду адаптивного потенціалу, який може бути реалізований у даних умовах середовища.

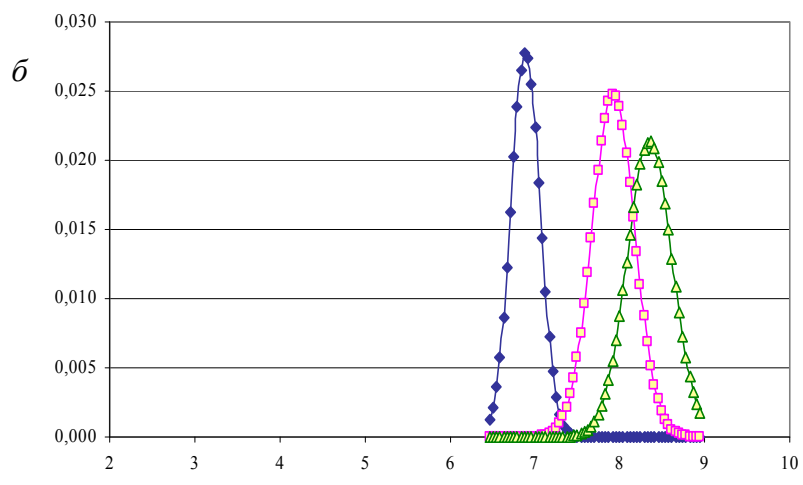

Рис. 4. Групи варіювання та сумарна крива розподілу питомої ваги листя A. tataricum: $a$ - Київ, $\sigma$ - Дніпропетровськ, в - Асканія-Нова; ряди 1-3 - складові сумарної кривої розподілу, ряд 4 - сумарна крива розподілу питомої ваги листя; за віссю абсцис - питома вага листя, мг $/ \mathrm{cm}^{2}$, за віссю ординат - щільність імовірності розподілу

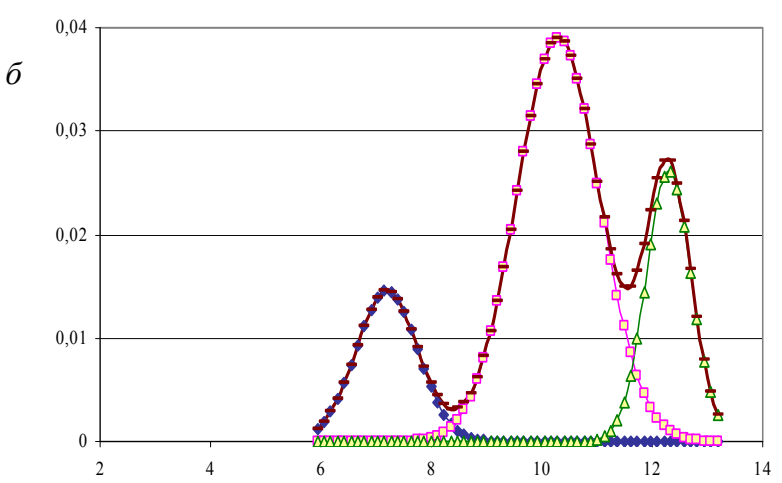

Рис. 5. Групи варіювання та сумарна крива розподілу питомої ваги листя $\boldsymbol{A}$. monspessulanum: $a$ - Донецьк, $\sigma$ - Одеса,, - Асканія-Нова; ряди 1-3 - складові сумарної кривої розподілу, ряд 4 - сумарна крива розподілу питомої ваги листя; за віссю абсцис - питома вага листя, мг $/ \mathrm{cm}^{2}$, за віссю ординат - щільність імовірності розподілу 
Відмічена для всіх видів кленів особливість звуження діапазону варіювання питомої ваги листя найбільшою мірою проявляється у малостійкого у степовій зоні $A$. saccharinum. У цього виду за більшої кількості компонентів сумарної кривої розподілу (до 4 компонентів у Дніпро-
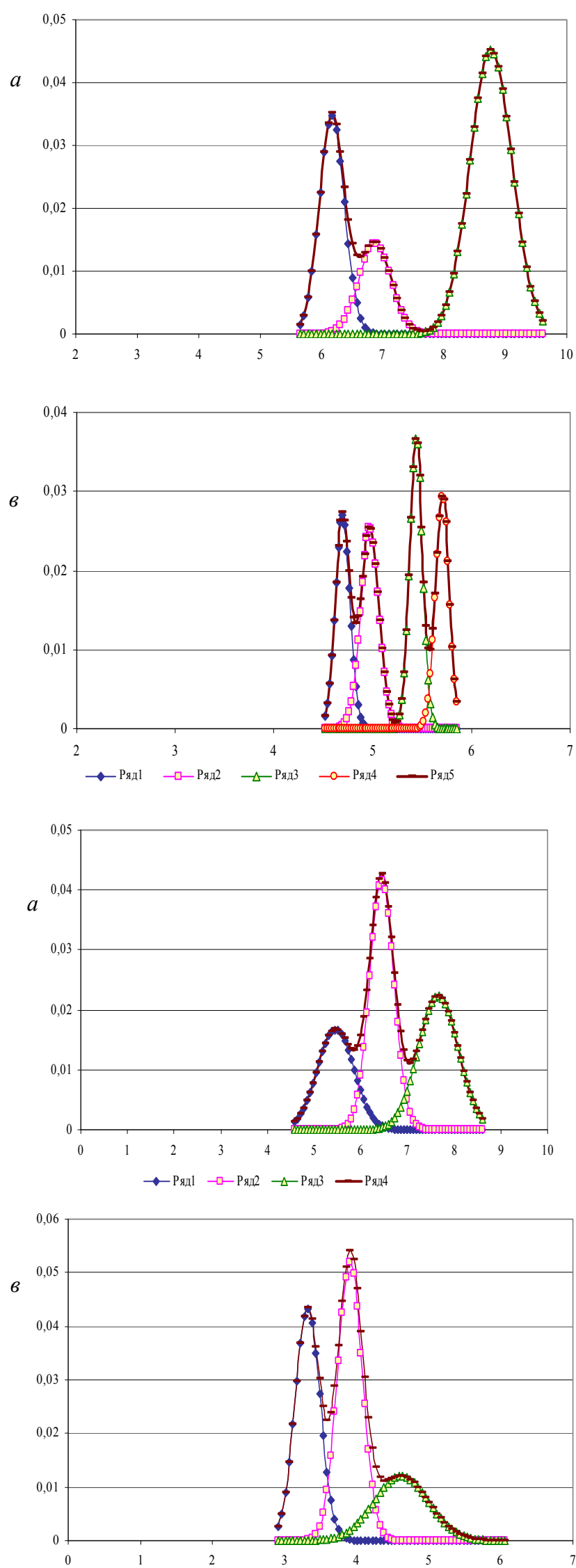

петровську, Кривому Розі, Асканії-Нові) (рис. 6), що ми трактуємо як ознаку нестійкого стану, спостерігаються певні характеристики кривої, які мають пристосувальні риси: дуже вузькі діапазони варіювання, а також чітке відокремлення кожного компонента.

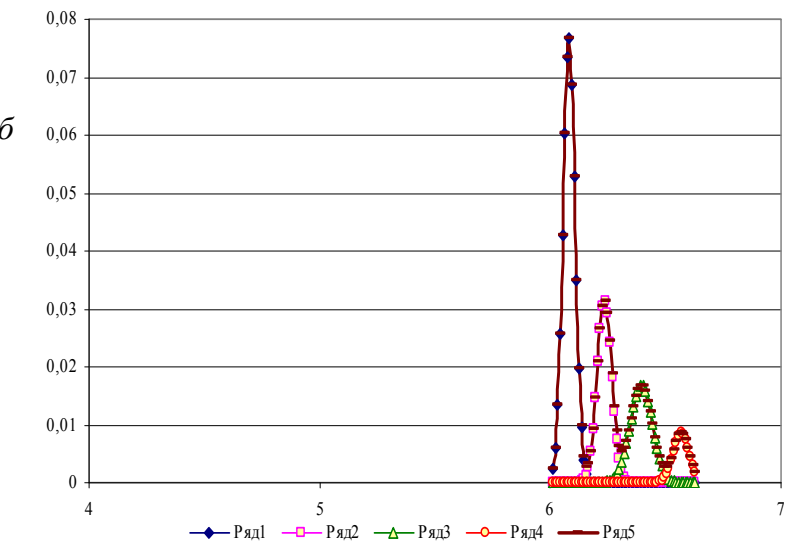

Рис. 6. Групи варіювання та сумарна крива розподілу питомої ваги листя $\boldsymbol{A}$. saccharinum: $a$ - Київ, $\sigma$ - Дніпропетровськ,, - Асканія-Нова; ряди 1-4 - складові сумарної кривої розподілу, ряд 5 - сумарна крива розподілу питомої ваги листя; за віссю абсцис - питома вага листя, мг $/ \mathrm{cm}^{2}$, за віссю ординат - щільність імовірності розподілу

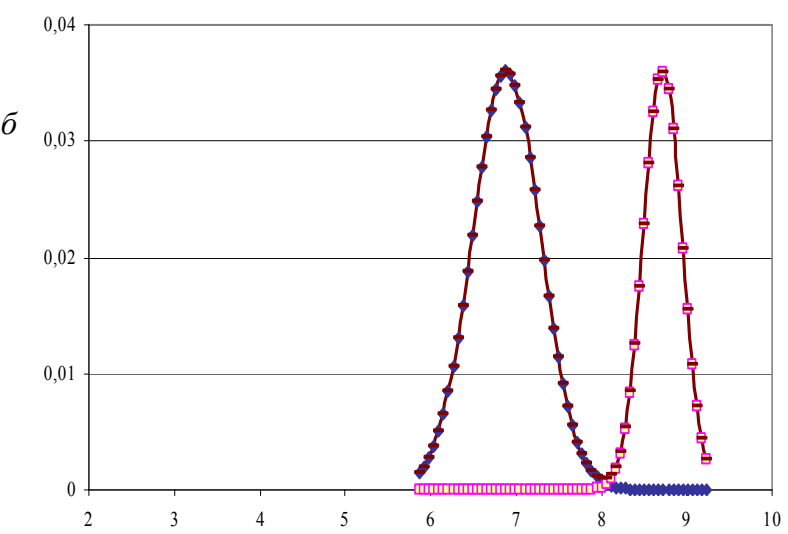

Рис. 7. Групи варіювання та сумарна крива розподілу питомої ваги листя $A$. campestre: $a$ - Київ, $\sigma$ - Кривий Ріг, в - Одеса;

ряди 1-3 - складові сумарної кривої розподілу, ряд 4 - сумарна крива розподілу питомої ваги листя; за віссю абсцис - питома вага листя, мг $/ \mathrm{cm}^{2}$, за віссю ординат - щільність імовірності розподілу 
Подібний характер диференціації листя за питомою вагою відмічено в A. platanoides і A. pseudoplatanus, що підтверджує недостатній ступінь адаптованості морфоструктурних ознак у цих видів. Так, у A. platanoides i A.pseudoplatanus питома вага листка майже не змінюється, досягаючи максимуму в Києві (рис. 3, табл.). Напевно, у південніших районах гідротермічні умови несприятливі для повноцінної фотоасиміляції та накопичення органічної речовини в листках A. platanoides A. pseudoplatanus.

Для видів із найвиразнішими ксероморфними ознаками (A. campestre, A. tataricum, A. monspessulanum) властиве послідовне збільшення як середньої величини одного 3
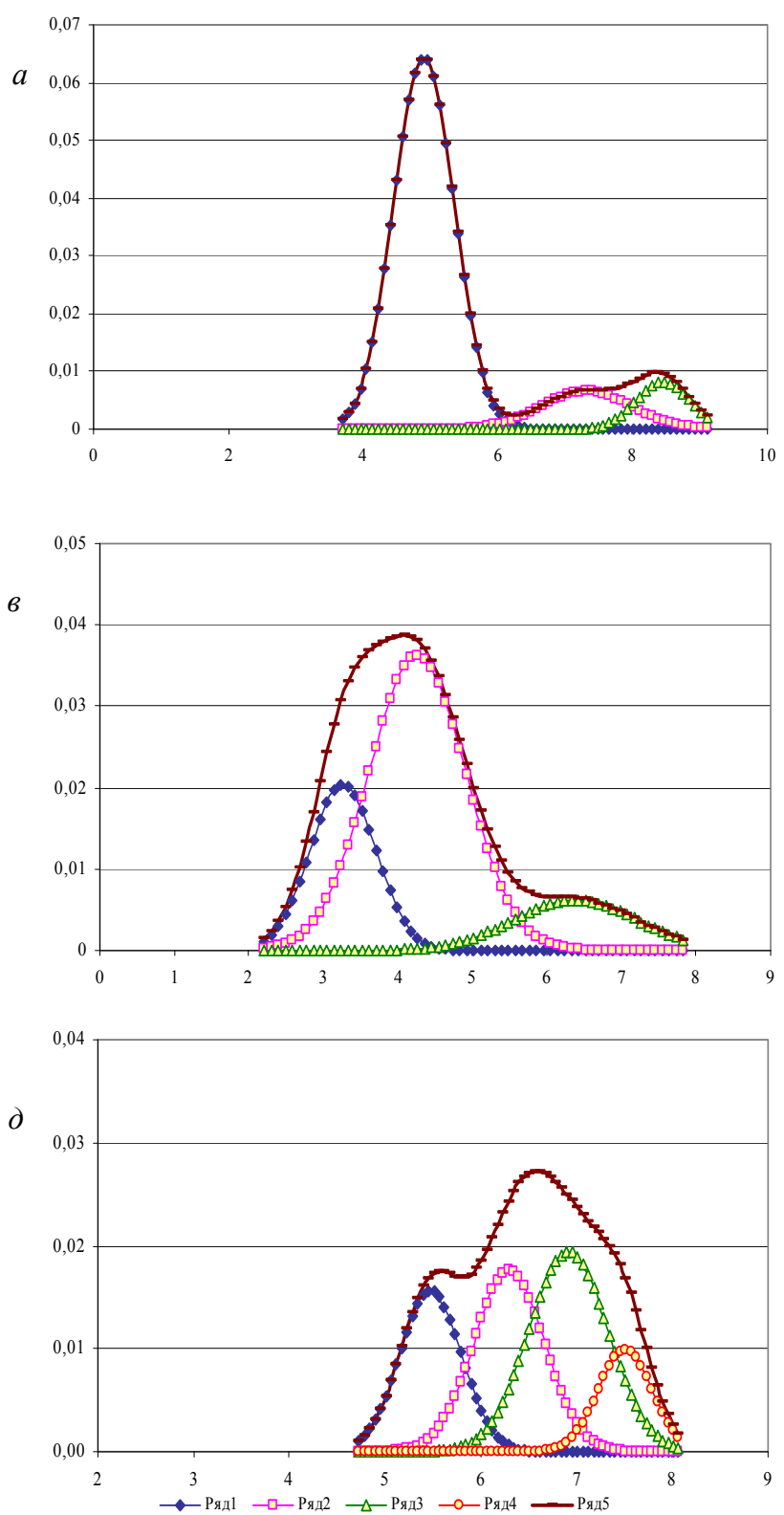

Для A. negundo, у якого виявлено адаптивний характер змін ознаки, найбільший ступінь диференціації одного 3 компонентів сумарної вибірки спостерігається у Києві $(0,794)$, причому це компонент із найменшою середньою величиною $\left(4,90 \pm 0,16 \mathrm{мг} / \mathrm{cm}^{2}\right)$ (рис. 8), що говорить про нестійкий характер пристосувальних морфоструктурних реакцій, пов'язаних із мезофільною спрямованістю фізіологічних процесів водообміну. У центральних та південно-східних районах степової зони при переважанні компонентів питомої ваги листя, так і його внеску до сумарної вибірки у міру посилення гідротермічного стресу в різних районах інтродукції у степовій зоні. Для A. campestre максимальні величини одного 3 найвагоміших компонентів складали в Києві 6,38 $\pm 0,08$ мг $/ \mathrm{cm}^{2}(0,760)$, у Кривому Розі - 6,85 $\pm 0,06$ мг/см² $(0,642)$, в Одесі - 6,98 \pm $0,12 \mathrm{мг} / \mathrm{cm}^{2}(0,588)$ (рис. 7). В A. tataricum і A. monspessulanum у найжорсткіших умовах Південного Степу значно зростає внесок у сумарну вибірку одного $з$ компонентів (рис. 4,5 ). В A. tataricum відносна частка, нормована до 1,0 , для компонента $5,56 \pm 0,15 \mathrm{Mr} / \mathrm{cm}^{2}$ складає 0,903 ; в A. monspessulanum для компонента 3 максимальною величиною $11,22 \pm 0,26 \mathrm{Mг} / \mathrm{cm}^{2}-0,784$.
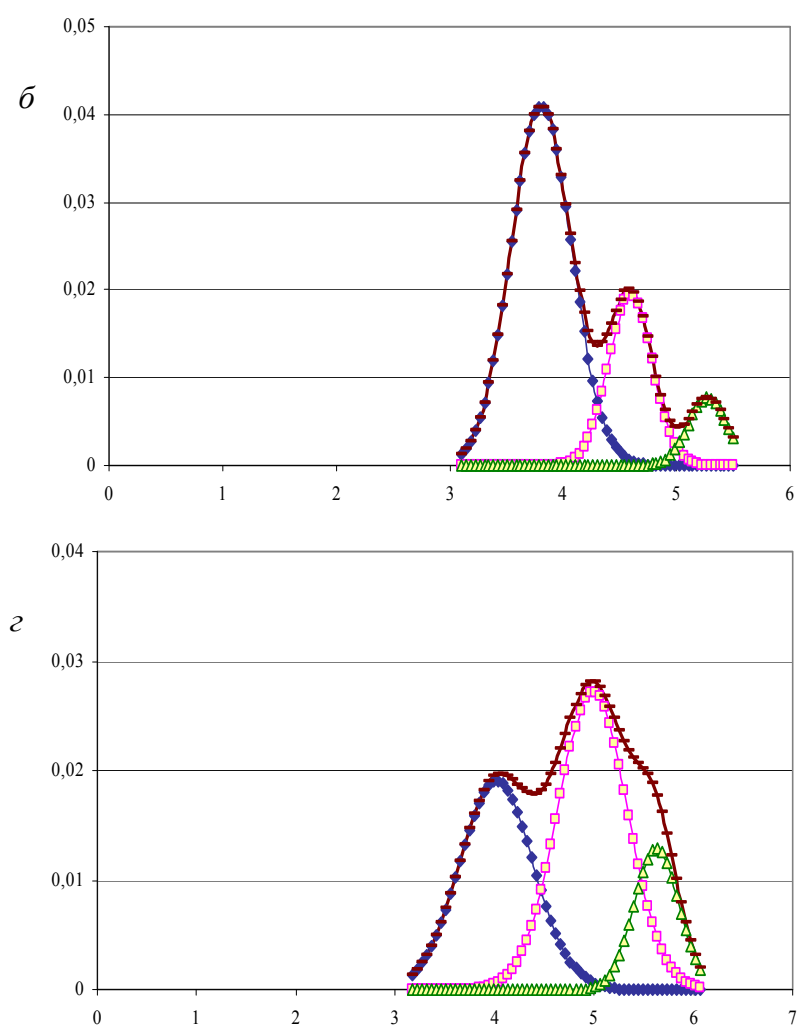

Рис. 8. Групи варіювання та сумарна крива розподілу питомої ваги листя $\boldsymbol{A}$. negundo:

$a$ - Київ, $\sigma$ - Дніпропетровськ, $в-$ Кривий Ріг, г - Донецьк, $\partial$ - Асканія-Нова;

ряди 1-4 - складові сумарної кривої розподілу, ряд 5 - сумарна крива розподілу питомої ваги листя; за віссю абсцис - питома вага листя, мг $/ \mathrm{cm}^{2}$, за віссю ординат - щільність імовірності розподілу

цього компонента в сумарному розподілі питомої ваги листя $A$. negundo, суттєво зростає вагомість компонентів із більшими та меншими величинами ознаки, тобто збільшується фенотипічне різноманіття, яке досягає максимуму в найжорсткіших гідротермічних умовах Південного Степу.

У континентальному Південному Степу в АсканіїНові виокремлюється 4-й компонент кривої 3 найбільшою питомою вагою листя 7,51 $\pm 0,26 \mathrm{мг} / \mathrm{cm}^{2}$, частка 
якого в сумарному розподілі досить велика $(0,123)$, що свідчить про пристосувальний характер мінливості морфоструктурних ознак листя $A$. negundo у посушливих умовах. Це підтверджується характером розподілу ознаки в іншому інтродукційному пункті у приморському Південному Степу. В Одесі максимуми двох переважаючих компонентів зсуваються у бік високих значень питомої ваги $-6,70 \pm 0,193$ і 6,99 $\pm 0,225 \mathrm{мг} / \mathrm{cm}^{2}$, частка яких складає 0,374 та 0,481 від сумарного розподілу ознаки. Стосовно $A$. negundo можна зазначити, що за результатами наших досліджень водообмінних процесів цей вид належить до типових мезофітів, тому морфоструктурні зміни, які мають ксероморфну спрямованість у різних районах степової зони, є одним із механізмів адаптації $A$. negundo до посушливих умов.

Таким чином, результати досліджень показали, що зміни показника питомої ваги листя кленів у посушливих умовах зростання мають різну спрямованість залежно від адаптивного потенціалу того чи іншого виду. Висновки, отрмані для видів роду Acer, які відрізняються ступенем мезо- та ксерофітності, у цілому підтверджуються даними щодо морфоструктурних особливостей і питомої ваги листків інших рослинних культур, у тому числі господарськи цінних. Slabbert and Krüger (2014) пов’язують зниження площі та ваги листка 3 посухостійкістю видів амаранту, поряд із такими фізіологічними ознаками як осморегуляція, накопичення проліну та стабільність клітинних мембран в умовах водного стресу. Анатомічні ознаки листків, спрямовані на зменшення розмірів і збільшення щільності клітин мезофілу, і, відповідно, усього листка, Bosabalidis and Kofidis (2002) відмічають на прикладі різних сортів деревних рослин Olea L., які культивуються у посушливих районах i піддаються хронічному впливу воднотемпературного стресу.

Установлене нами звуження довірчих інтервалів компонентів кривих розподілу питомої ваги листя кленів у ході пристосування до умов степової зони можна розглядати як додатковий фактор оцінки адаптивності морфоструктурних змін у посушливих умовах культивування інтродукованих деревних рослин. Зменшення інтервалу варіювання свідчить про те, що реалізовані у певних умовах фенотипічні прояви генотипічно зумовленої норми реакції є оптимальними для підтримання стійкого стану інтродуцентів у стресових умовах.

\section{Висновки}

У результаті застосування послідовних диференціювальних статистичних розподілів нормального виду усієї області варіювання ознаки встановлено іiі розподіл на дискретні компоненти 3 відповідними максимумами імовірності, що свідчить про диференціацію листків у кроні дерева за питомою вагою на групи, кожна 3 яких характеризується певною середньою величиною та амплітудою коливання ознаки біля середнього значення.

У більшості мезофітних видів кленів адаптивні реакції спрямовані на зниження фенотипічного поліморфізму в умовах степової зони, що проявляється у звуженні довірчих інтервалів складових компонентів сумарної кривої, а також зменшенні загального інтервалу варіювання питомої ваги листя.

У процесі онтогенетичної адаптації кленів до посушливих умов степової зони змінюється ступінь неоднорідності прояву морфоструктурних ознак листя. У стійких видів зростає величина щільності імовірності прояву (фенотипічної реалізаціiі) ознаки у певному діапазоні варіювання 3 вищою питомою вагою листка, тобто збільшується ксероморфність і ступінь адаптованості, або відповідності рослинного організму даним умовам середовища.

\section{Бібліографічні посилання}

Aranda, I., Pardo, F., Gil, L., Pardos, J.A., 2004. Anatomical basis of the change in leaf mass per area and nitrogen investment with relative irradiance within the canopy of eight temperate tree species. Acta Oecol. 25(3), 187-195.

Bobyliov, Y.P., Brygadyrenko, V.V., Bulakhov, V.L., Gaichenko, V.A., Gasso, V.Y., Didukh, Y.P., Ivashov, A.V., Kucheriavyi, V.P., Maliovanyi, M.S., Mytsyk, L.P., Pakhomov, O.Y., Tsaryk, I.V., Shabanov, D.A., 2014. Ekologija [Ecology]. Folio, Kharkiv (in Ukrainian).

Borisjuk, V.A., Kljachenko, V.I., Tretjak, T.V., 1989. Anatomomorfologicheskie i fiziologo-biohimicheskie testy pri izuchenii selekcionnyh materialov saharnoj svekly [Anatomicalmorphological, physiological and biochemical tests in the study of sugar beet breeding materials]. Kolos, Moscow (in Russian).

Bosabalidis, A.M., Kofidis, G., 2002. Comparative effects of drought stress on leaf anatomy of two olive cultivars. Plant Sci. 163(2), 375-379.

Bulakhov, V.L., Emel'janov, I.G., Pakhomov, O.Y., 2003. Bioraznoobrazie kak funkcional'naja osnova jekosistem [Biodiversity as functional basis of ecosystems]. Vìsn. Dnìpropetr. Unìv. Ser. Bìol. Ekol. 11(1), 3-8.

Burda, R.I., 1991. Antropogennaja transformacija flory [Anthropogenic transformation of the flora]. Naukova Dumka, Kyiv (in Russian).

Chen, X.-H., Gao, Y.-B., Zhao, T.-T., Zhu, M.-J., Ci, H.-C., Xiao-Yan, S., 2010. Morphological variations of Caragana microphylla populations in the Xilingol steppe and their relationship with environmenral factors. Acta Ecol. Sin. 30(2), 50-55.

Choat, B., Ball, M.C., Luly, J.G., Donnelly, C.F., Holtum, J.A.M., 2006. Seasonal patterns of leaf gas exchange and water relations in dry rain forest trees of contrasting leaf phenology. Tree Physiol. 26, 657-664.

Fang, J., Wu, F., Yang, W., Zhang, J., Cai, H., 2012. Effects of drought on the growth and resource use efficiency of two endemic species in an arid ecotone. Acta Ecol. Sin. 32(4), 195-201.

Feng, R., Zhang, Y., Yu, W., Hu, W., Wu, J., Ji, R., Wang, H., Zhao, X., 2013. Analysis of the relationship between the spectral characteristics of maize canopy and leaf area index under drought stress. Acta Ecol. Sin. 33(6), 301-307.

Kapustjan, A., Zhuk, O., 2009. Morfogenetychna adaptyvna vidpovid' roslyn na stres [Morphogenetic adaptive response of plants to stress]. Visnyk Kyi'vs'kogo Nac. Univ. Serija «Introdukcija ta zberezhennja roslynnogo riznomanittja» 26, 79-81 (in Ukrainian).

Kohno, N.A., 1982. Kleni Ukrayni [Maples of Ukraine]. Naukova Dumka, Kyiv (in Russian).

Kordjum, J.L., 2001. Fenotypichna plastychnist' u roslyn: Stan problemy ta perspektyvy [Phenotypical plasticity in plants: 
Problems and prospects of state]. Materialy IX Z'i'zdu Ukr. Bot. Soc. Harkiv 180-181 (in Ukrainian).

Niinemets, Ü., Kull, K., 2003. Leaf structure vs. Nutrienr relationship vary with soil conditions in temperate shrubs and trees. Acta Oecol. 24(4), 209-219.

Pakhomov, O.Y., Brygadyrenko, V.V., 2005. Koncepcija systemy zahodiv z ohorony navkolyshn'ogo pryrodnogo seredovyshha Dnipropetrovs'koi' oblasti na 2005-2015 roky [Concept of system for actions on environment protection in Dnipropetrovsk region for 2005-2015]. Vìsn. Dnìpropetr. Unìv. Ser. Bìol. Ekol. 13(1), 213-225.

Pakhomov, O.Y., Gasso, V.Y., Goloborodko, K.K., Poljakov, M.V., Grycan, Y.I., Bulakhov, V.L., Brygadyrenko, V.V., Kljuchko, Z.F., Mezhzherin, S.V., Novicky, R.O., Pysanec, Y.M., Pljushh, I.G., Ponomarenko, O.L., Puchkov, O.V., Radchenko, V.G., 2011. Chervona knyga Dnipropetrovskoi oblasti. Tvarynnyj svit [The red book of Dnipropetrovsk region. Animals]. New Print, Dnipropetrovsk (in Ukrainian).

Raskatov, P.B., 1979. Ekologycheskaja anatomyja vegetatyvnih organov derev'ev y kustarnykov [Ecological anatomy of vegetative organs of trees and shrubs]. Voronezh University Press, Voronezh (in Russian).

Rum'jankov, J., 2009. Anatomo-morfologichni oznaky kseromorfnosti lystkiv vydiv rodu Celtis L. v umovah Nacional'nogo dendroparku "Sofii'vka" NAN Ukrai'ny [Anatomical and morphological characteristics of leaves kseromorfity in species of Celtis L. in the National park "Sofiyivka", NAS Ukraine]. Introdukcija ta Zberezhennja Roslynnogo Riznomanittja 27, 143-144 (in Ukrainian).

Shavrov, L.A., 1961. Jekologo-geograficheskaja zakonomernost' strukturnoj izmenchivosti introducirovannyh rastenij [Eco- logical and geographical pattern of structural variability of introduced plants]. Botanicheskij Zh. 46(3), 328-336.

Slabbert, M.M., Krüger, G.H.J., 2014. Antioxidant enzyme activity, proline accumulation, leaf area and cell membrane stability in water stressed. South Afr. J. Bot. 95, 123-128.

Tooming, H.G., 1984. Ekologycheskye pryncypi maksymal'noj produktyvnosty posevov [Ecological principles of maximum productivity of crops]. Gidrometeoizdat, Leningrad (in Russian).

Waring, R.H., 1983. Estimating forest growth and efficiency in relation to canopy leaf area. Adv. Ecol. Res. 13, 327-354.

Zaitseva, I.A., 2004. Dynamika vodoobminnyh procesiv vydiv rodu Acer L. u zv'jazku z i'h posuhostijkistju [Waterprocesses dynamics for species of the Acer L. genus due to their drought]. Vìsn. Dnìpropetr. Unìv. Ser. Bìol. Ekol. 12(1), 54 62 (in Ukrainian).

Zaitseva, I.A., 2012. Izmenchivost' morfostrukturnyh priznakov list'ev drevesnyh introducentov roda Acer L. v stepnoj zone Ukrainy [Variability of morphostructural signs of leaves of Acer L. genus woody introducents in the steppe zone of Ukraine]. Visti Biosfernogo Zapovidnyka "Askanija-Nova" 14, 106-111 (in Russian).

Zajcev, G.N., 1983. Optimum i norma v introdukcii rastenij [Optimum and the norm in plant introduction]. Nauka, Moskow (in Russian).

Zhuang, L., Li, W.-H., Yuan, F., Gong, W.-C., Tian, Z.-P., 2010. Ecological adaptation characteristics of Populus euphratica and Tamarix ramosissima leaf microstructures in the lower reaces of Tarim River. Acta Ecol. Sin. 30(2), 62-66.

Надійшла до редколегї 25.10.2014 